\title{
Turizm Sektörü Çalışanlarında Atalet Yordayıcısı Olarak İş Yaşamında Yalnızlık (Loneliness in The Workplace As a Inertia Predictor of Tourism Sector Employees)
}

\section{Gamze ÖZEL iD a Aydın İNAK iD b}

a Kilis 7 Aralık Üniversitesi, Turizm ve Otelcilik Meslek Yüksekokulu, Otel, Lokanta ve İkram Hizmetleri, Kilis, Türkiye. gozel@kilis.edu.tr

b Gaziosmanpaşa Üniversitesi, Reşadiye Meslek Yüksekokulu, Yönetim ve Organizasyon, Tokat, Türkiye. aydin.inak@gop.edu.tr

\section{MAKALE BİLGİsi \\ Anahtar Kelimeler: \\ İş yaşamında yalnızlık \\ Atalet \\ Turizm sektörü}

Gönderilme Tarihi 16 Mart 2021

Revizyon Tarihi 3 Temmuz 2021

Kabul Tarihi 10 Temmuz 2021

Makale Kategorisi:

Araştırma Makalesi

\section{ÖZET}

Amaç - Bu çalışmada turizm sektörü çalışanlarının iş yaşamındaki yalnızlıklarının atalet düzeylerine etkisini belirlemek amaçlanmıştır.

Yöntem - Araştırmada örgütsel yalnızlığın boyutları olan duygusal yoksunluk ve sosyal arkadaşlığın ataletin boyutları olan ögrrenme ataleti ve deneyim ataleti üzerinde etkisini ölçemeye yönelik model oluşturulup, modele uygun hipotezler geliştirilmiştir. Araştırmanın çalışma evrenini konaklama tesislerinde çalışan iş görenler oluşturmakta olup, 384 örneklem sayısı olarak belirlenmiştir. Araştırmada kullanılan veriler online anket yöntemi ile ulaşılan 447 personelden toplanmıştır. Elde edilen veriler sosyal bilimlerde kullanılan istatistik paket programı ile analiz edilerek raporlanmıştır.

Bulgular - Araştırma sonucuna göre işgörenlerin; örgütsel yalnızlık düzeylerinin 3,37 olduğu, atalet düzeylerinin 3,21 olduğu tespit edilmiştir. Aynı zamanda araştırma sonucunda göre iş yaşamında yalnızlığın ataleti pozitif yönde ve doğrusal olarak etkilediği sonucuna ulaşılmıştır.

Tartışma - Araştırmada elde edilen analiz sonuçlarına göre iş yaşamında yalnızlığın çalışanlarda atalet halinin oluşmasında etkili olabileceğini söylemek mümkündür. Araştırmanın uygulanma aşamasında mevcut covid-19 salgını çalışanlara ulaşma anlamında sınırlılık olarak karşımıza çıkmıştır. Bu nedenle çalışmanın sürecin normale dönmesiyle birlikte daha geniş bir örneklem grubuyla tekrarlanmasında fayda bulunmaktadir.

\begin{tabular}{|c|c|}
\hline ARTICLE INFO & ABSTRACT \\
\hline Keywords: & Purpose: In this study, it is aimed to determine the effect of loneliness in the workplace in the tourism \\
\hline Loneliness in The & sector on their level of inertia. In this context, regression analysis was carried out to determine the effect \\
\hline Workplace & of loneliness on inertia in business life. \\
\hline Inertia & Design/methodology/approach: In the research, models were created to measure the effect of emotional \\
\hline Tourism Sector & deprivation and social friendship on learning inertia and experience inertia, which are the dimensions of \\
\hline & organizational loneliness, and developed hypotheses suitable for the model. The population of the study \\
\hline Received 16 March 2021 & is those working in the accommodation facilities, 384 sample numbers are considered sufficient. The data \\
\hline Revised 3 July 2021 & used in the study were collected from 447 personnel using a online survey method. The obtained data \\
\hline Accepted 10 July 2021 & were analyzed and reported with the statistical package program used in social sciences. \\
\hline \multirow[t]{2}{*}{$\begin{array}{l}\text { Article Classification: } \\
\text { Research Article }\end{array}$} & $\begin{array}{l}\text { Findings: According to the results of the research; It was determined that loneliness in the workplace } \\
\text { level was } 3.37 \text { and inertia level was } 3.21 \text {. At the same time, according to the results of the research, it was } \\
\text { concluded that loneliness in the workplace life affects inertia positively and linearly. }\end{array}$ \\
\hline & $\begin{array}{l}\text { Discussion: According to the analysis results obtained in the study, it is possible to say that loneliness in } \\
\text { business life can be effective in the formation of inertia in employees. During the implementation phase } \\
\text { of the study, the current covid-19 epidemic appeared as a limitation in terms of reaching employees. } \\
\text { Therefore, it is beneficial to repeat the study with a larger sample group as the process returns to normal. }\end{array}$ \\
\hline
\end{tabular}




\section{GİRISS}

Turizm sektörü ülkeler açısından rekabet gücü yüksek, sürekli olarak gelişmeye devam etmekte olan emek yoğun niteliğe sahip bir sektördür. Bu kapsamda hizmeti üreten ve sunan en önemli unsurlardan biri insandır. Dolayısıyla hizmete ilişkin kalite, imaj ve misafir memnuniyeti gibi unsurların oluşturulmasında çalışanların payı oldukça büyüktür. Bu nedenle çalışanların memnuniyet düzeylerini artıracak kavramların dikkate alınması, çalışanlarla birlikte işletmelerin verimliliklerinin artırılmasında etkili olacaktır.

Turizm sektöründe faaliyet gösteren işletmelerin başarılarının büyük ölçüde insan kaynağına bağlı olduğu düşünüldüğünde çalışanları etkileyebilecek kavramların dikkate alınması gerekliliği düşünülmektedir. Bu kapsamda yalnızlık kişinin çalışma arkadaşlarıyla ilişki kuramaması ve onlardan uzaklaşması sonucunda hissettiği rahatsızlık ve ruhsal zorlanma şeklinde ifade edilebilir. İş yaşamında yalnızlık bireyin kendini bir gruba ait hissetmemesi veya ait olduğu gruptan dışlanması şeklinde oluşabileceği gibi bireyin kendini uzaklaştırması şeklinde de oluşabilir. Bu durum bireyi psikolojik olarak etkileyen bir durumdur (Bozkurt, 2019: 63). Yalnızlık yaşayan bireyin kendilerini örgütten soyutlama durumunda kalmaları takım çalışmasının önemli olduğu turizm sektöründe uygun çalışanlar olmaktan uzaklaşmalarına neden olacaktır.

Dinamik bir yapıya sahip olan turizm sektöründe durağanlık işletmenin başarısızlığına neden olabilecektir. Bu kapsamda atalet kavramı harekete geçmeme veya geç harekete geçme, yapılması gerekenleri zamanında yapmama (Sekman, 2009: 15), birey veya çalışanların karar verme ya da problem çözme gibi durumlarda mevcut metotlara başvurmalarını öngörmektedir (Aksoy ve Türk, 2015: 8). Atalet, yüksek rekabet ortamında bir işletmenin hayatta kalmasını tehlikeye atabilecek veya avantajını baltalayabilecek yenilik ve beklenen davranış eksikliği ile sonuçlanacaktır. Bu nedenle, bir kuruluş veya işletme için, öğrenme kabiliyeti üzerindeki ataletin olumsuz etkisinden kaçınılarak bilgiyi verimli ve etkili şekilde kullanabilmek önemlidir (Liao, Fei, Liu, 20008: 184). Bu durumda çalışanların değişimlere, yeni bilgilere açık olmaları, harekete geçmeleri dolayısıyla atalet halinde olmamaları başarıya hızlı bir şekilde ulaşılmasını sağlayacaktır.

Çalışma hayatında sosyal ya da duygusal anlamda yeterli ve doyurucu ilişkilerin paylaşılmadığı ortamlar oluştuğu takdirde çalışanların kendilerini rahat hissetmeleri ve başarılı olmaları mümkün değildir. Bu ortamlarda çalışanlarda işten ayrılma niyetlerinde artış ve performans düşüklügünün olmasıyla birlikte (Dönmez ve Topaloğlu, 2020: 321), örgütsel bağlılı̆̆ın (Dönmez ve Topaloğlu, 2020: 321; Jung, Song ve Yoon, 2021: 10), işe bağlılığın (Jung, Song ve Yoon, 2021: 10) iş tatmininin (Dönmez ve Topaloğlu, 2020: 321; Boz ve Alan, 2021: 266) azalması gibi olumsuz sonuçlarla karşı karşıya kalınabilmektedir. Böylelikle yaşanan yalnızlık ile birlikte psikolojik sağlığı ve iş performansı olumsuz yönde etkilenen bireylerde kişisel veya örgütsel hedefler arasında dengesizlik oluşarak, çalışanların iş tatmini ve üretkenliğinin düşmesine başarısızlık korkusunun oluşmasına kendini yetersiz hissetmesine ve algılanan iş stresinin artmasına neden olabilir (Boz ve Alan, 2021: 266). Bu kapsamda iş yaşamında yalnızlık yaşayan bireylerde dışlanmışlık hissi veya kendini örgüte ait hissetmeme gibi durumlar sonucunda iş tatmini azalarak ve işten ayrılma niyeti artan çalışanlarda yılgınlık, tükenmişlik, tembellik ve atalet hali oluşabilir bu durum ise memnuniyet oluşturmayı ve başarıya ulaşmayı engelleyecektir. Turizm sektörü emek yoğun bir sektör olması sebebiyle işi gerçekleştiren ve sunan dolayısıyla misafir memnuniyetini oluşturan unsur çalışanlardır. Başarıyı elde etmede büyük paya sahip olan çalışanların görevlerini yerine getirebilmeleri için atalet veya yalnızlık halinde olmamaları gerekmektedir. Bu nedenle işletmelerin imajını oluşturacak, kaliteli hizmet sunumu gerçekleştirecek ve misafirlerin zihninde yer yaratacak işgörenlerin motivasyonları ve performanslarını olumsuz yönde etkileyebilecek yalnızlık veya atalet üzerinde durulması gereken kavramlar olarak düşünülmektedir.

Bu çalışmanın amacı turizm sektörü çalışanlarının iş yaşamındaki yalnızlıklarının atalet düzeylerine etkisini belirlemektir. Bu kapsamda konaklama tesisleri çalışanlarının iş yaşamında yalnızlık ve atalet düzeylerinin tespit edilmesi, ilişkilendirilmesi ve iş yaşamında yalnızlığın çalışanların atalet düzeylerine etkilerinin belirlenmesi sektör ve sektör yöneticileri açısından önem arz etmektedir.

\section{KAVRAMSAL ÇERÇEVE}

\section{1. İş Yaşamında Yalnızlık}

Yalnızlık, bireyin kabul görme, ait olma, onaylanma, sosyalleşme gibi ihtiyaçlarının gereken ölçüde karşılanamaması sonucunda kendisini ötekileştirmesi ya da soyutlamasıyla oluşan içsel tecrübedir. Yalnızlık 
yaşayan bireylerin yapması gereken görev ve sorumlulukları gerçekleştirmesi, huzurlu bir yaşam sürdürmesi veya sağlıklı olması mümkün görünmemektedir (Yakut ve Certel, 2016: 72). Yalnızlık aslında öznel bir yapı olup; kendini algılayan kişilerarası yetersizlik, bireyin kişisel özellikleri ile sosyal çevreleri arasındaki tutarsızlığın nasıl yaşandığını ortaya çıkarmaktadır (Peplau ve Perlman, 1982 Aktaran Wright, 2005: 10). Yalnızlık, mevcut ilişkiler ve ilişki standartları arasındaki bir uyuşmazlığın bilişsel değerlendirmesinin olumsuz sonucu olarak tanımlanır (Gierveld, Tilburg ve Dykstra, 2006: 495). Bireyler sosyal hayatlarında bulunan farklı konum ve statüde olan bireylerle oluşturdukları ilişkilerle yaşamlarını devam ettirmekte olup yaşanan ilişkilerin olumlu veya olumsuz etkileri bulunabilmektedir (Yılmaz ve Aslan, 2013: 60).

Genel yalnızlıktan farklı olarak iş hayatında oluşan yalnızlık sadece iş ortamında görülmektedir. Normal yaşamında sosyal ilişkileri kuvvetli olan kişiler iş yaşamında sosyal ilişkiler kurmakta zorluk yaşayabilmektedir. Yaşanan bu durum bireyin iş yaşamında yalnızlık ve dışlanmışlık hissetmesine neden olmaktadır (Doğan, Çetin ve Sungur, 2009: 272). İşyerleri bireylerin sosyal ilişkilerinin geliştirme açısından fırsatlar yaratan ortamlar olarak görünse de iş yaşamında daima iyi ilişkilerin ve dostlukların var olduğunu söylemek pek doğru değildir. Örgütsel yaşamdaki yalnızlık kişilerarası iyi ilişkilerin yoksunluğundan ortaya çıkan sorun şeklinde tanımlanabilir (Çetin ve Alacalar, 2016: 196). İnsanların bir grubun parçası olma diğer bireylerle bağlantı kurma, çevresindeki insanlarla sosyal etkileşimler kurma gibi istekleri ve kendilerini bir gruba ait hissetme gereksinimleri bulunmaktadır (Besse, 2016: 1). Yaşanan yalnızlık kaygıya doğru ilerler çünkü kaygıyı hafifletmek için başka bir kişi veya grup aramayı içerir. Tersi durumda ise yakınlık kaygısı ya da bağımlılık kaygısı, bireyin geri çekilmesine ve yalnızlık hissetmesine neden olabilir (Anderson, 1993: 585).

İş yaşamında yalnızlık iki şekilde gerçekleşir bunlar; duygusal yoksunluk ve sosyal arkadaşlıktır. Duygusal yoksunluk; bireyin arzulanan bir dostluk ya da işyerinde çalışan başka bireyle kişisel bağlantısının olmadığını algılamasıyla hissedilen yoksunluk durumunu ifade ederken, sosyal arkadaşlık ise bireyin sosyal uyum ve sosyal ağlarla ilgili eksiklikler sonucunda kendini ekibin bir parçası olarak görmemesi sonucunda oluşmaktadır (Wright, 2005: 76). Duygusal yoksunluk; iş yaşamında kişilerarası ilişkilerin kalitesini ifade etmekte (Çetin ve Alacalar, 2016) ve çalışma ortamında diğer bireylerle yakın bağ kuramama sonucunda ortaya çıkmaktadır (Yurcu ve Kocakula, 2015: 32). Bireylerin yaşadıkları ölüm, boşanma gibi olumsuzluklar duygusal yalnızlığın sebepleri olabilmektedir. Tedirginlik, yaşanan endişeler, tarif edilemez korkular, diğer bireylerin sevecen davranışlarını önyargılı yorumlama, küçük detaylara aşırı duyarlılık gibi durumlar duygusal yalnızlık yaşayan bireylerde görülen belirtilerdir (Demirbaş ve Haşit, 2016: 139). Sosyal arkadaşlık ise bireyin sosyal ilişkilerinin yokluğu sonucunda ortaya çıkmakta ve ortak amaçları bulunan bir grup içerisinde bulunamıyor olmayı (Yurcu ve Kocakula, 2015: 32), bireyin destek almak için bağlantı kurabileceği sosyal ağların eksikliğini ifade eder (Besse, 2016: 4). Sosyal arkadaşlık; çalışma arkadaşı, akran, komşu ile olan ilişki ağı ve arkadaş sayısının yetersizliğinden oluşan duygu durumudur. Çalışılan işyerinde sosyal ilişkilerin yoksunluğu ve bireyin kendini kabul edecek bir grubun içinde yer bulamıyor olması sosyal yalnızlığı göstermektedir. Sosyal yalnızlık sonucunda çalışanlarda reddedilme hissi, çabuk sıkılma ve utangaçlık gibi durumlar oluşabilmektedir (Mercan, Demirci, Özler ve Oyur, 2015: 199).

Bireylerin iş yaşamında yalnızlık yaşamaları sonucunda çalışanlarda ve işletmelerde verimlilik kayıpları oluşabilmektedir. Bu kayıpların önüne geçmek için yalnızlık duygusunun engellenmesi gerekmektedir (Keser ve Karaduman, 2014: 181). Aynı zamanda bireyler iş yaşamında yalnızlık yaşadıklarında takım çalışmasında başarı gösteremeyerek düşük performans sergileme durumunda kalacaklardır. Takım çalışmasının önemli olduğu sektörlerde yalnızlık yaşayan bireyler kendilerine yer bulamayacaklardır. Yalnızlık yaşayan birey kendini işine veremeyecek ve performansının düşmesiyle birlikte kariyeri önünde engel de oluşturacaktır (Bozkurt, 2019: 67). Aynı zamanda iş görenlerin yalnız hissetmeleri sonucunda motivasyonları düşmekte, performansları azalmakta ve iş tatminleri de olumsuz olarak etkilenmektedir. Bunun sonucunda işletmenin verimlilik elde etmesi, rekabet avantajı elde edebilmesi pek mümkün olmamaktadır (Akbaba, 2020: 1713). İş tatmini olumsuz etkilenen işgörenlerin işe bağllı̆̆g ve adanmışlığı azalacaktır. Üretkenliğin azalmasıyla beraber işverenlerle sorunların yaşanması ve işten ayrılma gibi durumlar yaşanacaktır. Örgüt içerisinde mevcut iletişimde oluşabilecek bozulmalar çalışanlar arasında kutuplaşmalara neden olacak ve bilgi aktarımında sorunlar oluşabilecektir. Çalıştıkları işletmeye duygusal bağlllığı azalan çalışanlarda işe geç gelme, mazeret uydurarak işe gelmeme, izin ve rapor kullanma gibi 
durumlar oluşacaktır. Yalnız kalan bireylerin iş arkadaşlarıyla arasında mesafe bulunması sonucunda yapılan ortak faaliyetlere katılmamasından dolayı destek mekanizması zayıflayarak, örgüte uyumda sorunlar oluşacaktır (Bozkurt, 2019: 67).

Yapılan çalışmalarda, işyeri arkadaşlı̆̆ının işgören performansını etkilediği (Uluçay ve Zengin, 2020: 46), yalnız bireylerin düşük benlik saygısına ve zayıf psikolojik sağlamlığa sahip olduğu (Güloğlu ve Karaırmak, 2012: 81), işyeri yalnızlığının örgütsel sinizm üzerinde etkisi olduğu (Ay, 2015: 1124), işyerinde yalnızlı̆̆ın işten ayrılma niyeti üzerinde etkisi olduğu (Demirbaş ve Haşit, 2016: 152, Erdirençelebi, Ertürk ve Çini, 2020: 46) belirlenmiştir. Aynı zamanda örgütsel yalnızlı̆̆ın temel nedeninin örgütteki ilişki ve iletişim eksikliği olduğunu belirten Tınaztepe (2012) yaptığı çalışmada; örgüt içi iletişimin örgütsel sinizm üzerinde anlamlı negatif yönde etki olduğunu tespit etmiştir. Akbaba (2020); tarafından yapılan çalışmada turizm işletmelerinde uygulanan insan kaynakları yönetimi uygulamaları etkinliği ile iş yaşamında yalnızlık arasında negatif yönlü ilişki tespit edilmiştir.

Çalışma hayatında başarılı olabilmek için, iş arkadaşlarıyla uyum sağlayabilmek ve iyi ilişkiler kurmak önemlidir. Çalışma arkadaşlarıyla uyumlu olabilen ve çalışmaktan mutluluk duyan bireylerin verimlilikleri ve yaratıcılıkları artacak böylelikle yüksek performans göstereceklerdir. İşgörenlerin yüksek performans göstermeleri, örgütün sürdürülebilirliği ve rekabet avantajı elde edebilmesi bakımından oldukça önemlidir (Uluçay ve Zengin, 2020: 45). Bu kapsamda turizm sektöründe faaliyet gösteren işletmelerin verimlilik elde etmeleri ve rekabet avantajı sağlamalarında çalışanların etkisi göz önüne alındığında iş yaşamında yalnızlık kavramının önlenmesi gereken bir durum olduğunu varsaymak mümkündür.

\subsection{Atalet}

Atalet kavramı, farklı disiplinler tarafından değişik şekillerde tanımlanmaktadır. TDK'ya göre; tembellik, işsiz kalma, işlemezlik olarak tanımlanan kavramın kelime anlamı eylemsizlik hali olup, atıl kökünden gelmektedir (https://sozluk.gov.tr/). Fizikte atalet prensibi, cisimlerin dışarıdan değişik yön ve şiddetlerde bir kuvvetin etkisi olmadan hareketsiz kalacağı, ivmeye karşı direnç göstereceğini ifade eder. İnsanlar doğrusal olarak ilerleyen bir cismin hareketlerini takip edince varış noktasını tahmin ederek ona ulaşabilirler. İnsan zihni ve algısında da atalet olabileceği aslında bu fenomenden ortaya çıkmaktadır. Ataletin insan davranışlarına uyarlanmış halinde bireyin veya çalışanların karar verme ya da problem çözme gibi durumlarda mevcut metotlara başvurmalarını öngörmektedir (Aksoy ve Türk, 2015: 8). Bu kapsamda sosyal bilimlerde atalet; harekete geçmeme veya geç harekete geçme durumu olup eylem yeteneklerinin zayıflı̆̆ını ifade etmektedir (Sekman, 2009: 11). Atalet hali bireysel olarak başlayıp örgütsel ataletin oluşmasına temel oluşturabilmekte ve birbirlerini desteklemektedir. Örgütsel atalete düşmemek için öncelikle bireysel ataleti yenmek gerekmektedir (Karayel, 2014: 32). Örgütler açısından atalet firsatları değerlendirememek, eylemsiz kalmak tamamen durağan olmayı değil çok yavaş ve gönülsüz olarak değişmelerini ifade eder (Bakan, Sezer, ve Kara, 2017: 124). Geçiş yapabilmek için değişime hızlı veya etkili şekilde tepki veremeyen bir örgüt yetersizliği şeklinde ifade edilen örgütsel atalette örgüt var olanı korumak için değişime karşı direnç gösterme eğilimindedir (Roodt ve Kinnear, 2003: 1). Atalet aslında krizin meydana geliş süreci içerisinde yer almaktadır. Bu aşamada krizi oluşturan etkenleri uzaklaştırmak gerekmektedir. Durumun kendiliğinden geçeceği, müdahale etmenin maliyetinin yüksekliği gibi durumlar krizin çözümünde olumsuz etkiye neden olacaktır (Yakut Aymankuy, 2001). Atalet bilgi(öğrenme) ve deneyim ataleti olmak üzere iki alt boyutta ele alınabilir. Bilgi ataleti; yeni bilgilerin öğrenilmesi önünde engel olarak görülürken, deneyim ataleti ise problem çözme aşamasında bilgi ve tecrübelerin etkisini ifade eder (Küçükergin, 2012: 41).

Bilgi ataletinde birey geçmiş deneyim ve bilgilerini yeterli görerek yeni bilgiler edinme noktasında etkisiz duruş sergilemektedir. Birey günlük hayatından karşılaştığı olaylara verilen tepkiler sonucunda öğrenme köklerini oluşturur (Aksoy ve Türk, 2015: 8). Yeni bir sorunu çözmek için geçmiş bilgiyi yeniden kullanmak, durum artık mümkün olmayana ve sonra dış güçler tarafından değiştirilene kadar benzer şeylerin statik veya tekdüze kalacağı bir yasa veya ilke haline gelir (Liao, 2002: 21). Bilgi ataleti aynı zamanda örgütsel öğrenme ve yenileşmeyi de olumsuz yönde etkilemekte ve örgüt performansında düşüşe sebep olmaktadır. Öğrenen birey ve örgütlerin rekabet gücü elde edebileceği ve çevresel koşullarda oluşabilecek değişimlere uyum sağlayabileceği düşünüldüğünde; bilginin yoğunluğu, yeniye olan eğilim, bireylerin zihinsel sermayesi ve üretkenlik gibi konuların örgütlerin başarıyı elde etmeleri için önemli olduğu söylenebilir 


\section{G. Özel - A. İnak 13/3 (2021) 2188-2202}

(Karayel, 2014: 18). Bu durumda atalet halinde olan bireylerin başarıyı sağlamasının mümkün olduğu söylenemez.

Deneyim ataleti boyutunda; birey karşılaştıkları herhangi bir durumu daha önceden kazandığı deneyimlerle çözmeye çalışmasını ifade eder. Bu durumda birey geçmiş deneyimlerinin geleceğine ket vurmasına müsaade ederek karşılaştığı herhangi bir durumda yeni veya farklı yönden bir bakış açısı geliştirmesine engel oluşturur. Örgütlerde meydana gelen deneyim ataleti de işgörenler, örgüt yapısı, teknolojilerde uygulanabilecek yenilikler veya yaratıcı bakış açısıyla oluşturulabilecek düşüncelerin, değişimlerin oluşmasına ve hayata geçirilmesine engel oluşturmaktadır (Çavuş ve Pekkan, 2017). Çevre koşullarında sürekli değişimler meydana gelmekte, bu koşullara uyum sağlamak bireylerin kendilerini geliştirmeleri, yenilikleri uygulayabilmeleri ile mümkün olmaktadır. Böylelikle koşullara göre kendini yenileyerek, dinamik bir yapıya sahip olabilir. Ancak örgüt içerisinde bir tek öğrenen bireyin olması da o örgüt için yeterli değildir. Örgütte bulunan her bireyin kendi alanlarıyla ilgili konularda yenilikleri takip etmesi, öğrenmesi ve uygulayabilmesi gerekmektedir (Karayel, 2014: 20).

Ataletin pek çok nedeni olabilir. Bunlar; amaçsızlık, kişilik yapısı, erteleme alışkanlığı, parasızlık, mükemmeliyetçilik, öğrenilmiş çaresizlik, yabancılaşma, iş tatminsizliği, iç çatışmalar olarak sıralanabilir (Sekman, 2009: 25). Atalet halinde olan birey eski alışkanlıklarından, düşüncelerinden kolay vazgeçmemekte, yeniliklerin kendilerini destekleyebileceğini kabul etmediklerinde uyum sağlamayı istememektedirler. Aslında bu durum ataletin oluşumunun kaynağıdır (Çankaya ve Demirtaş, 2010: 2). Bireylerin değişime uyum sağlayabilmeleri ve atalete düşmelerini engelleyebilmek için motivasyon araçları kullanılabilir. Aynı zamanda cesaret, kararlılık, sevgi, samimiyet, başarı hissi, kendine güven vb. insanları harekete geçiren duygulardan da yararlanılabilir (Sekman, 2009: 73). Çalışanların kendilerini yetkin hissedebilmeleri, motive olmaları, harekete geçme arzusu göstermeleri için takım çalışması, açık iletişim, kendilerini geliştirme imkanlarının sunulması, performansa dayalı geri bildirim gibi teşvik edici uygulamalar yapılmalıdır. Böylelikle yetenekleri ve yaratıcılıkları ile işgörenlerin memnuniyet düzeyleri artacak böylelikle atalet haline düşmeleri engellenerek değişimlere uyum sağlamaları gerçekleşecektir (Karayel, 2014: 33). Turizm sektörü dinamik bir yapıya sahip olduğundan başarıya ulaşmak için değişime uyum sağlamak önemlidir.

Turizm sektöründe değişim ve yeniliklere açık öğrenmeye hevesli bir örgüt iklimi oluşturmak hem çalışanlar hem de işletme açısından önem arz etmektedir. Çalışanlara hizmet içi eğitimlerin verilmesi, iş tanımlarının yapılması ve çalışma koşullarının iyileştirilmesi bireylerin atalet haline dönüşmelerini engelleyebilecektir. Böylelikle tembel, tükenmiş, yorgun çalışanlar yerine çalışanların memnuniyeti ile misafir memnuniyeti ve dolayısıyla işletme başarısı elde edilmiş olacaktır. Durgun olan otel işletmelerinde de bu durumu yok edebilmek için dengeleri bozacak ve rekabet ortamı oluşturacak çatışmalar yaratılmaktadır (Topaloğlu, 2010: 99). Küresel rekabetin olduğu ortamda işletmelerin değişime açık olması gerekmektedir. Teknoloji ve fiziksel yeniliklerin yanı sıra yeni yönetim tekniklerinin de uygulanması gerekmektedir. Aynı zamanda tüketicilerin beklentilerinde oluşabilecek değişiklikler fark edip harekete geçmesi işletmelerin başarılı olmasını sağlamaktadır (Şahin, Kutluk, Mayuk ve Köstekli, 2011: 570). Turizm sektöründe Şahin vd. (2011) tarafından yapılan çalışmada; otel işletmelerinde uygulanan değişim çalışmalarının işgörenlerin performansları ve memnuniyetlerini olumlu yönde etkilediği sonucuna ulaşılmıştır. Bu nedenle sektör çalışanlarının değişime açık olmaları ile performanslarının yükseleceği, atalet halinde olan bireylerin ise değişime açık olmamalarının iş tatminlerini ve performanslarını olumsuz etkileyeceği söylenebilir.

İşyeri esnekliği açısından, otel çalışanlarının sosyal ilişkilerini geliştirmeye ve yalnızlık duygularını yönetmeye yönelik çabalar, otel endüstrisinin sürdürülebilir büyümesini kolaylaştırabilir (Jung, Song ve Yoon, 2021: 2). Turizm endüstrisi sosyal ve ekonomik faydalarını insan odaklı bir anlayış çerçevesinde gerçekleştirmelidir. İnsan gücüne dayalı olan bu endüstride kişilerarası güvenin rolü oldukça büyüktür. Turizm sektöründe sunulan hizmetler birbiriyle entegre şekilde sunulmaktadır. Bu bütünleşmenin sağliklı şekilde sürdürülebilmesi ise ancak güven ile mümkün olabilmektedir (Özkoç, 2014: 39). Yalnızlık yaşayan bireylerin güven duyması pek mümkün olmadığından hizmetlerde olumsuzluklarla karşılaşılacağı böylelikle hem çalışanlar hem de hizmet sunulan misafirlerin memnuniyet düzeylerinin azalacağı söylenebilir. Aynı zamanda kişileri farkına varmadan etkileyen kavram olan atalet özellikle sezon boyunca yoğun iş temposunda çalışan işgörenlerde yorgunluk, tükenmişlik, tepkisizlik ve tembelliğe sürükleyerek 


\section{G. Özel - A. İnak 13/3 (2021) 2188-2202}

hayatlarını ve işlerini dolayısıyla örgütü etkileyebilir. Bu durumda hizmetlerin sunumu sırasında çalışanlarda atalet halini görebilmek olasıdır. Bununla birlikte yalnızlık yaşayan bireylerin kendilerini soyutlamaları böylelikle çalıştıkları işyerlerini kendileri için olumsuz bir ortam olarak görmeleri performansları üzerinde de etkili olacaktır. Yalnızlık aynı zamanda bireyleri psikolojik olarak da etkilemekte ve motivasyonları azalan çalışanların kendini geliştirme, değişime uyum sağlama, yeni bilgiler elde etme noktalarında atıl duruş sergilemelerine dolayısıyla atalet haline düşmelerine neden olacağ da söylenebilir. İnsan faktörünün önemli olduğu turizm sektöründe memnun çalışanların memnun misafir oluşturacağ 1 fikrinden hareketle sektör yöneticilerinin tarafından çalışanların yalnızlık hissetmeyecekleri veya atalet haline düşmeyecekleri bir sistemin işletme içerisinde yerleştirilmesi gerekmektedir. Bu kapsamda turizm sektöründe oluşabilecek ve işletme imajını da etkileyebilecek bu iki kavramın önemsenmesi ve kendiliğinden yok olmayacak kavramlar olarak gereken müdahalelerin yapılması önem arz etmektedir. Literatür taramalarında iş yaşamında yalnızlığın olumsuz etkileri görülmüş bu nedenle çalışanlarda atalet haline de neden olabileceği düşünülmüş olup iki kavramı birlikte ele alan çalışmaya literatürde rastlanmamıştır.

\section{YÖNTEM}

\subsection{Araştırma Modeli ve Hipotezleri}

Araştırma kapsamında belirlenen değişkenlere göre bir araştırma modeli hazırlanmıştır. Hazırlanan model araştırma modelleri arasından deneme modelidir. Model yapılan araştırma sonunda ulaşılması istenen amaca uygun şekilde biçimlendirilmiştir. Elde edilen nicel verilerin rasyonel ve sağlıklı bir şekilde değerlendirilmesi sağlayacaktır (Şekil 1).

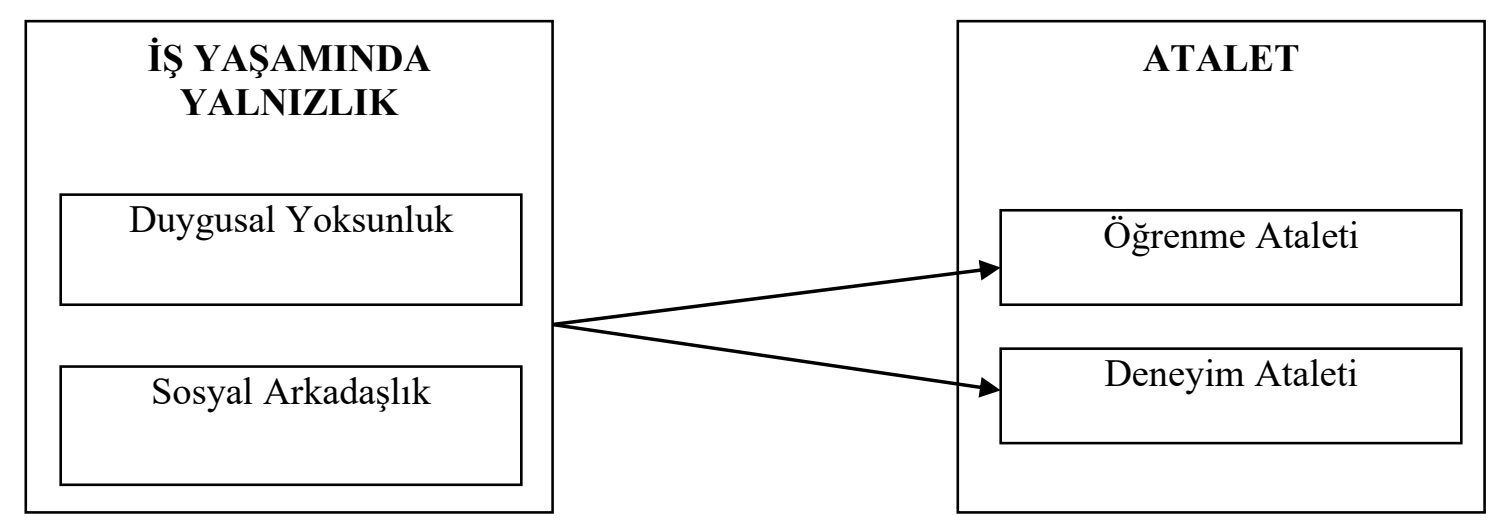

Şekil 1: Araştırma Modeli

Araştırma modelinin çözümlenmesini sağlayacak, araştırmanın kavramsal çerçevesine uygun araştırma hipotezleri oluşturulmuştur. Geliştirilen hipotezler şunlardır:

H: İş yaşamında yalnızlığın öğrenme ataleti üzerine anlamlı bir etkisi vardır.

$H_{1 a:}$ Duygusal yoksunluğun öğrenme ataleti üzerine anlamlı bir etkisi vardır.

$\mathbf{H}_{1 b:}$ Sosyal arkadaşlığın öğrenme ataleti üzerine anlamlı bir etkisi vardır.

$\mathbf{H}_{2}$ : İş yaşamında yalnızlığın deneyim ataleti üzerine anlamlı bir etkisi vardır.

$\mathbf{H}_{2 a}$ : Duygusal yoksunluğun deneyim ataleti üzerine anlamlı bir etkisi vardır.

$\mathbf{H}_{2 b}$ : Sosyal arkadaşlı̆̆ın deneyim ataleti üzerine anlamlı bir etkisi vardır.

\subsection{Evren Örneklem}

$\mathrm{Bu}$ çalışmada turizm sektörü çalışanlarında atalet yordayıcısı olarak iş yaşamında yalnızlık incelenmiştir. Araştırmanın evrenini konaklama tesisleri çalışanları oluşturmaktadır. Evrenin 100.000 ve üzeri olması durumunda örneklem sayısının 384 olarak kabul edildiğinden (Altıunışık, Coşkun, Bayraktaroğlu ve Yıldırım, 2005: 127) örneklem sayısı 384 olarak belirlenmiştir. Araştırma kapsamında örnekleme ulaşmak 


\section{G. Özel - A. İnak 13/3 (2021) 2188-2202}

amacıyla kolayda örnekleme yöntemi kullanılmıştır. Dünya genelinde etkili olan Covid-19 salgını nedeniyle çalışanlara temassız ulaşabilmek adına online anket uygulaması ile oluşturulan formlar konaklama tesisleri çalışanlarına e-posta, forumlar, bloglar, sosyal ağlar ile ulaştırılmış ve 447 anketten geri dönüş alınabilmiştir.

\subsection{Verileri Toplama Araci}

Veri toplama aracı olarak hazırlanan anket formu 3 bölümden oluşmaktadır. Anketin birinci bölümünde katılımcıların özelliklerine ilişkin ifadelere yer verilmiştir. Anketin ikinci bölümünde çalışanların iş yaşamında yalnızlık düzeylerini belirlemeye yönelik Wright vd. (2006) tarafından geliştirilen ve Türkçeye uyarlaması Doğan vd. (2009) tarafından yapılan duygusal yoksunluk boyutuna ilişkin 9 ifade, sosyal arkadaşlık boyutuna ilişkin 7 ifade olmak üzere toplam 16 ifadeden oluşan "İş Yaşamında Yalnızlık Ölçeği" kullanılmıştır. Anketin son bölümünde ise Liao vd. (2008) tarafından geliştirilen ve Çankaya (2010) tarafından Türkçeye uyarlaması yapılan öğrenme ataletine ilişkin 7 ifade, deneyim ataletine ilişkin 7 ifade olmak üzere toplam 14 ifadeden oluşan "Atalet Ölçeği" kullanılmıştır. İş yaşamında yalnızlık ve atalet ile ilgili ölçekte yer alan tüm ifadeler 5'li Likert şeklinde, 1=Kesinlikle Katılmıyorumdan 5=Kesinlikle Katılıyoruma kadar derecelendirilerek oluşturulmuştur.

\subsection{Verilerin Analizi}

Araştırma sonucunda elde edilen veriler ile katılımcıların özelliklerine ilişkin betimleyici istatistikler, iş yaşamında yalnızlık ile atalet arasındaki ilişkiyi belirlemeye yönelik korelasyon, atalet yordayıcısı olarak iş yaşamında yalnızlığı belirlemeye yönelik regresyon analizleri uygulanmıştır. Araştırmanın uygulanmaya başlamasından önce Kilis 7 Aralık Üniversitesi etik kurulunun 24.08.2020 tarihli ve Z-76062934-044 nolu kararı ile etik onay alınmıştır.

\section{BULGULAR}

Yapılan araştırma kapsamında elde edilen veriler ışığında uygun istatistiki analizler gerçekleştirilerek aşağıda açıklanmıştır.

\section{1. Ölçeklere İlişkin Güvenilirlik ve Geçerlilik Analizi}

Araştırma değişkenlerinin normal dağılıma uygunluğu test edilmiştir. George ve Mallery (2010)'e göre ilgili değişken +2 ve -2 aralığında basıklık ve çarpıklık değerine sahip olması durumunda normal dağılım sergilemektedir. Yapılan normallik testi sonuçlarına göre elde edilen bulgular basıklık (min: -1.170, max: .100) ve çarpıklık (min: -.772, max: .256) değerlerinin \pm 2 değerleri arasında olduğu ve normal dağım sergilediği görülmektedir.

Araştırma çerçevesinde iş yaşamında yalnızlık ölçeğine faktör analizi uygulanmış ve faktör yapısı araştırılmıştır. Uygulanan faktör analizinde ölçekte yer alan ifadelerin yeterli faktör yükü almalarından dolayı ölçekten herhangi bir ifadenin çıkarılmasına gerek duyulmamıştır. Sonraki aşamalarda yapılan analizler 16 ifade üzerinden uygulanmıştır.

Uygulanan faktör analizi sonucunda iş yaşamında yalnızlık ölçeğinde yer alan 16 ifade 2 faktör altında toplanmıştır. Belirlenen faktörler toplam varyansın \%76,58'ini açıklamıştır. Analiz sonucunda Kaiser-MayerOlkin (KMO) örneklem yeterliliğinin \%51,2 olduğu görülmektedir. Ayrıca Bartlett küresellik test değeri, 0,000 düzeyinde anlamlı olup; değer 9077,191 çıkmıştır. Tablo 1'de iş yaşamında yalnızlık ölçeğine uygulanan faktör analizi sonuçlarına yer verilmiştir. 
G. Özel - A. İnak 13/3 (2021) 2188-2202

Tablo 1: İş Yaşamında Yalnızlık Ölçeği Faktör Analizi Sonuçları

FAKTÖRLER

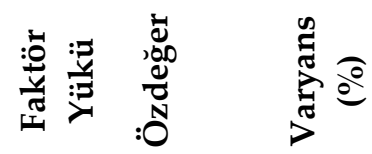

Duygusal Yoksunluk (9 İfade)

6,374

39,839

9. İş yerindeyken kendimi genel bir boşluk duygusu içinde hissederim.

, 942

4. Kendimi iş arkadaşlarımdan duygusal olarak uzak hissediyorum. ,933

7. İş arkadaşlarımla birlikteyken çoğu zaman kendimi dışlanmış hissediyorum.

,920

8. İş yerinde çoğu zaman diğer çalışanlarla birlikte aramda bir kopukluk hissederim.

,914

3. Birlikte çalıştığım insanlarla arama mesafe koyduğumu hissediyorum

,914

2. Çoğunlukla iş arkadaşlarımın bana mesafeli durduklarını hissediyorum.

1. İş ortamında baskı altındayken iş arkadaşlarım tarafından yalnız bırakıldığımı hissederim.

, 845

5. İs yerimdeki ilişkilerimden memnunum.

, 814

6. Çalıştı̆̆ım iş yerinde dostluk anlayışı hakimdir.

, 776

Sosyal Arkadaşlık (7 İfade)

, 767

15. Kendimi iş yerindeki arkadaş grubunun bir parçası olarak hissederim. $\quad, 930$

14. İş yerinde mola zamanlarında beraber vakit geçirebileceğim biri vardır $\quad$,928

16. İş yerinde beni dinleme zahmetinde bulunan insanlar vardır. $\quad, 905$

11. İş yerimdeki sosyal etkinliklere (piknik, parti, yemek vs.) katılııım. $\quad, 888$

12. İş yerinde gerektiğinde işle ilgili günlük sorunlarımı konuşabileceğim biri vardir.

13. İş yerinde istediğimde kişisel düşüncelerimi paylaşabileceğim kimse yoktur.

$\frac{\text { 10. İş yerinde sosyal ilişkilerim vardır. }}{\text { Açılanan Toplam Varyans: \%76,58; Kaiser-Meyer-Olkin örneklem yeterliliği: \%81,2 }}$

, 885

Bartlett küresellik testi: X2: 9077,191; s.d.: 120, p<0.000;

Faktör analizi sonucunda elde edilen birinci faktör, 9 ifadeden oluşmaktadır. Faktör toplam varyansın \%39,839'unu açıklamaktadır. Birinci faktör altında yer alan ifadeler incelendiğinde, bu faktör 'Duygusal Yoksunluk' olarak isimlendirilmiştir. Yapılan faktör analizi sonucu, elde edilen ikinci faktör ise 7 ifadeden oluşmakta ve toplam varyansın \%36,744'ünü açıklamaktadır. İkinci faktör altında yer alan ifadeler incelendiğinde, bu faktör 'Sosyal Arkadaşlık' olarak isimlendirilmiştir.

Araştırma çerçevesinde atalet ölçeğine faktör analizi uygulanmış ve 14 ifade üzerinden uygulanan faktör analizinde ifadelerin tamamının faktör yükünün yeterli olduğu belirlenmiştir. Daha sonra yapılan analizlere 14 ifade üzerinden devam edilmiştir.

Uygulanan faktör analizi sonucunda atalet ölçeğinde yer alan 14 ifade 2 faktör altında toplamıştır. Belirlenen faktörler toplam varyansın \%75,56'sını açılamaktadır. Analiz sonucunda Kaiser-Mayer-Olkin (KMO) örneklem yeterliliğinin \%79,7 olduğu görülmektedir. Ayrıca Bartlett küresellik test değeri, 0,000 düzeyinde anlamlı olup; değer 7252,222 çıkmıştır. Tablo 2'de atalet ölçeğine uygulanan faktör analizi sonuçlarına yer verilmiştir. 
G. Özel - A. İnak 13/3 (2021) 2188-2202

Tablo 2: Atalet Ölçeği Faktör Analizi Sonuçları

\section{FAKTÖRLER}

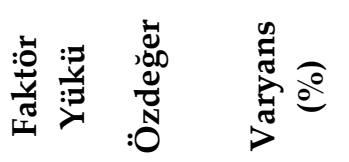

\begin{tabular}{lcc}
\hline Öğrenme Ataleti (7 İfade) & $\mathbf{6 , 0 2 1}$ & $\mathbf{4 3 , 0 0 6}$ \\
\hline $\begin{array}{l}\text { 6. Yeni bilgi kaynakları arama girişiminde bulunmayacağım. } \\
\begin{array}{l}\text { 2. Yeni problemlerle karşılaştı̆̆ımda çözmek için yeni yaklaşımlar } \\
\text { kullanmayacağım. }\end{array}\end{array}$ &, 941 & \\
\hline
\end{tabular}

3. Eski düşüncelerimi ve davranışlarımı değiştirmek için yeni fikirler öğrenmeye çalışmayacağım.

1. Çalıştı̆̆ım kuruluş bana yeni kavram ve yöntemler öğrenme fırsatı sunmaz. $\quad$, 862

7. Çalışma hayatımda yeni bilgi ve deneyimler öğrenmem gerekmiyor. $\quad, 840$

4. Diğer insanların problemleri nasıl çözdüğünü gözlemleyemiyorum.

5. Sorunları çözmek için nadiren farklı yaklaşımlar kullanıyorum. 683

\begin{tabular}{lrl}
\hline Deneyim Ataleti (7 İfade) & 4,558 & 32,557 \\
\hline
\end{tabular}

13. Geçmişte öğrendiğim bilgiler ve elde ettiğim deneyimler işimdeki

verimliliğimi arttırmaktadır.

, 903

12. Öğrendiğim birçok şeyi, genellikle yaşadığım olaylardan ve edindiğim deneyimlerden öğrenirim.

11. Geçmişte öğrendiğim bilgiler ve kazandığım deneyimler, yeni bilgileri/doğruları kabul edip etmememde çok belirleyici bir rol oynamaktadır.

14. Benzer bir sorunla karşılaştığımda sorunu bildiğim eski yöntemlerle çözmeye çalışırım.

10. Problemleri bildiğim deneyimlerimle çözmeye çalışırım.

, 874

8. Yeni bilgiler elde etmek için genellikle aynı kaynaklara başvururum ve yeni

bilgi kaynakları aramaya çalışmam

9. Geçmişte öğrendiğim bilgilere ve kazandığım deneyimlerime işimde ve hayatımda çok güvenirim.

,901

, 875

, 814

, 800

Kaiser-Meyer-Olkin örneklem yeterliliği: \%79,7; Bartlett küresellik testi: X2: 7252,222; s.d.: 91, p<0.000;

Genel Açıklanan Toplam Varyans: \%75,56

Atalet ölçeğine uygulanan faktör analizi sonucunda ulaşılan birinci faktör, 7 ifadeden oluşmaktadır. Faktör toplam varyansın \%43,006'sını açıklamaktadır. Birinci faktör altında yer alan ifadeler incelenerek “Öğrenme Ataleti" olarak isimlendirilmiştir. Uygulanan faktör analizi sonucunda elde edilen ikinci faktörde 7 ifadeden oluşmaktadır. İkinci faktör toplam varyansın \%32,557'sini açıklamaktadır. İkinci faktör altında toplanan ifadeler incelenerek "Deneyim Ataleti" olarak isimlendirilmiştir.

Araştırma dâhilinde oluşturulan ölçümlerin güvenirlik analizi yapılmıştır. Buna göre iş yaşamında yalnızlık ölçeği güvenilirlik katsayısı, Alpha $(\alpha)=0,87$; atalet ölçeğinin güvenilirlik katsayısının, Alpha $(\alpha)=0,92$ olduğu görülmektedir. Elde edilen bulgulara göre, araştırmada kullanılan ölçümlerin güvenirliliklerinin yüksek derecede olduğunu söylemek mümkündür. Tablo 3 'te uygulanan güvenilirlik analizi sonuçları gösterilmektedir.

Tablo 3: Ölçümlerin Güvenirlik Katsayıları

\begin{tabular}{lcc}
\hline \multicolumn{1}{c}{ Ölçekler } & Cronbach's Alpha & İfade sayısı (N) \\
\hline İş YAŞAMINDA YALNIZLIK & $\mathbf{0 , 8 7}$ & $\mathbf{1 6}$ \\
\hline Duygusal Yoksunluk & 0,90 & 9 \\
\hline Sosyal Arkadaşlik & 0,86 & 7 \\
\hline ATALET & $\mathbf{0 , 9 2}$ & $\mathbf{1 4}$ \\
\hline Öğrenme Ataleti & 0,94 & 7 \\
\hline Deneyim Ataleti & 0,89 & 7 \\
\hline
\end{tabular}


G. Özel - A. İnak 13/3 (2021) 2188-2202

\subsection{Katılımcılara İlişkin Özellikler}

Araştırmaya dahil olan katılımcılara ilişkin özellikleri belirlemek amacıyla betimleyici istatistiklerden frekans ve yüzde analizleri uygulanmıştır. Tablo 4 'te katılımcılara ilişkin özellikler detaylandırılmıştır.

Tablo 4: Katılımcıların Özelliklerine İlişkin Bulgular

\begin{tabular}{l|l|c|c}
\hline Değişkenler & & f & \% \\
\hline Cinsiyet & Kadın & 243 & 54,4 \\
& Erkek & 204 & 45,6 \\
\hline \multirow{5}{*}{ Yaş } & 20 ve altı yaş & 6 & 1,3 \\
& 21-30 yaş arası & 200 & 44,7 \\
& 31-40 yaş arası & 145 & 32,4 \\
& $41-50$ yaş arası & 90 & 20,1 \\
& 51 ve üzeri yaş & 6 & 1,3 \\
\hline Medeni durum & Bekar & 238 & 53,2 \\
& Evli & 209 & 46,8 \\
\hline \multirow{5}{*}{ Eğitim durumu } & İköğretim & 6 & 1,3 \\
& Lise & 44 & 9,8 \\
& Önlisans & 116 & 26,0 \\
& Lisans & 177 & 39,6 \\
& Lisansüstü & 104 & 23,3 \\
\hline \multirow{5}{*}{ Departman } & Önbüro & 71 & 15,9 \\
& Yiyecek-İçecek & 147 & 32,9 \\
& Kat Hizmetleri & 49 & 11,0 \\
& Muhasebe & 61 & 13,6 \\
& Teknik Servis & 21 & 4,7 \\
& Satış Pazarlama & 43 & 9,6 \\
& İnsan Kaynakları & 55 & 12,3 \\
\hline Toplişma Süresi & $0-5$ yıl & 186 & 41,6 \\
& 6-10 yıl & 183 & 40,9 \\
& $11-15$ yıl & 54 & 12,1 \\
& 16 yıl ve üzeri & 24 & 5,4 \\
\hline
\end{tabular}

Tablo 4'e göre katılımcıların \%54,4'ü kadın (n: 243), \%45,6'sı erkek (n: 204), \%44,7'si 21-30 yaş aralığında (n: 200), \%32,4'ü 31-40 yaş aralığında (n: 145), \%53,2'si evli (n: 238) ve \%46,8'i bekârdır (n: 209). Katılımcıların eğitim durumlarına bakıldığında ise büyük çoğunluğun önlisans (\%26,0; n: 116), lisans (\%39,6; n: 177) ve lisanüstü (\%23,3; n: 104) düzeylerinde oldukları görülmektedir. Katılımcların çalıştıkları departmanları incelendiğinde, \%15,9'unun önbüro (n: 71), \%32,9'unun yiyecek-içecek (n: 147), \%11,0'inin kat hizmetleri (n: 49), \%12,3'ünün insan kaynakları (n: 55), \%9,6'sının satış pazarlama (n: 43), \%13,6'sının muhasebe (n: 61) ve \%4,7'sinin teknik serviste (n: 21) görev aldıkları görülmektedir. Katılımcıların çalışma sürelerine göre dağılımları incelendiğinde, \%41,6'sının 0-5 yıl arasında (n: 186), \%40,9'unun 6-10 yıl arasında (n: 183), \%12,1'inin 11-15 yıl arasında (n: 54) ve \%5,4'ünün ise 15 yıl ve üzeri (n: 24) süre ile meslekte çalıştıkları tespit edilmiştir. 
G. Özel - A. İnak 13/3 (2021) 2188-2202

\subsection{Değişkenlere İlişkin Tanımlayııı İstatistikler}

Araştırma kapsamında ölçülmesi amaçlanan değişkenlere ve alt boyutlarına yönelik genel ortalama ve standart sapma değerleri Tablo 5'de detaylandırılmıştır.

Tablo 5: Değişkenlere İlişkin Aritmetik Ortalama ve Standart Sapma Değerleri

\begin{tabular}{lll}
\hline \multicolumn{1}{c}{ Ölçekler } & Aritmetik Ortalamalar & \multicolumn{1}{c}{ Standart Sapma } \\
\hline İŞ YAŞAMINDA YALNIZLIK & $\mathbf{3 , 3 7}$ & $\mathbf{6 7}$ \\
\hline Duygusal Yoksunluk & 3,12 &, 93 \\
\hline Sosyal Arkadaşlık & 3,69 &, 76 \\
\hline ATALET & $\mathbf{3 , 2 1}$ &, $\mathbf{8 0}$ \\
\hline Öğrenme Ataleti & 2,82 & 1,07 \\
\hline Deneyim Ataleti & 3,59 &, 78 \\
\hline
\end{tabular}

Genel olarak katılımcıların iş yaşamında yalnızlık düzeyleri incelendiğinde ortalamanın üzerinde sonuçlar ile karşılaşılmaktadır $(X=3,37$; ss= 0,67$)$. Boyutlar bazında incelendiğinde duygusal yoksunluk boyutu $(X=$ 3,12; ss=0,93) ve sosyal arkadaşlık boyutu $(X=3,69$; ss= 0,76$)$, ortalamalara sahip olduğu görülmektedir. Genel olarak katılımcıların atalet düzeyleri incelendiğinde yine ortalamanın üzerinde sonuçlar ile karşılaşılmaktadır $(X=3,21 ; \mathrm{ss}=0,80)$. Boyutlar bazında incelendiğinde deneyim ataleti boyutunda $(X=3,59$; $\mathrm{ss}=0,78)$ ortalamanın üzerinde ve öğrenme ataleti boyutunda ise $(X=2,82 ; \mathrm{ss}=1,07)$ ortalamanın altında değerlere sahip olduğu görülmektedir.

\subsection{Değişkenlerarası İlişkilere Yönelik Korelasyon Analizi Sonuçları}

Turizm sektöründe çalışan işgörenlerin iş yaşamında yalnızlık ve atalet düzeyleri arasındaki ilişkiyi belirlemek amaciyla yapılan korelasyon analizi sonuçları Tablo 6 'da detaylandırılmıştır.

Tablo 6: İş Yaşamında Yalnızlık ve Atalet İlişkisine Yönelik Korelasyon Katsayıları

\begin{tabular}{|c|c|c|c|c|c|c|}
\hline & (1) & (2) & (3) & (4) & (5) & (6) \\
\hline İş Yaşamında Yalnızlık (1) & 1 & & & & & \\
\hline Duygusal Yoksunluk (2) & $871^{* *}$ & 1 & & & & \\
\hline Sosyal Arkadaşlık (3) &, $643^{* *}$ & $184^{* *}$ & 1 & & & \\
\hline Atalet (4) &, $711^{* *}$ & $617^{* *}$ &, $462^{* * *}$ & 1 & & \\
\hline Öğrenme Ataleti (5) & $652^{* *}$ & $700^{* *}$ & $214^{* * *}$ & , $905^{* * *}$ & 1 & \\
\hline Deneyim Ataleti (6) &, $566^{* *}$ & $306^{* *}$ & $655^{* *}$ & $811^{* *}$ & $485^{* *}$ & 1 \\
\hline
\end{tabular}

Korelasyon analizi sonucunda, iş yaşamında yalnızlık değişkenini oluşturan boyutlar ile ataleti oluşturan boyutlar arasında genel olarak düşük ve orta düzeyde pozitif yönlü ve anlamlı bir ilişki olduğu tespit edilmiştir. İş yaşamında yalnızlığın duygusal yoksunluk boyutunun, ataletin öğrenme ataleti $(r=0,700, p=$ $, 000<0,05)$ ve deneyim ataleti $(r=0,306, p=, 000<0,05)$ boyutları ile arasında pozitif yönlü ve anlamlı ilişki bulunmaktadır. Bu kapsamda işgörenlerin duygusal yoksunlukları attıkça öğrenme ve deneyim ataletlerinin artacağını söylemek mümkündür. İş yaşamında yalnızlığın sosyal arkadaşlık boyutunun, ataletin öğrenme ataleti $(r=0,214, p=, 000<0,05)$ ve deneyim ataleti $(r=0,655, p=, 000<0,05)$ boyutları ile arasında anlamlı ve pozitif yönlü ilişki bulunduğu görülmektedir. Bu bağlamda işgörenlerin sosyal arkadaşlık düzeyi arttıkça bilgi ve deneyim ataleti düzeylerinin de artacağı söylenebilir. Ayrıca iş yaşamında yalnızlığın, atalet $(\mathrm{r}=$ $0,711, p=, 000<0,05)$ ile anlamlı ve arasında pozitif yönlü ilişki bulunmaktadır. Bu kapsamda işgörenlerin iş yaşamında yalnızlık düzeyleri arttıkça atalet düzeylerinin de yükseleceğini söylemek mümkündür.

\subsection{Değişkenlerarası Uygulanan Regresyon Analizi Sonuçları ve Hipotez Testleri}

Araştırmanın bu bölümünde iş yaşamında yalnızlık ölçeğinin her bir boyutunun öğrenme ataleti üzerinde anlamlı bir etkisi olup olmadığını belirleyebilmek amacıyla çoklu regresyon analizi uygulanmıştır. Tablo 7 'de iş yaşamında yalnızlığın öğrenme ataleti düzeyleri üzerine etkisini inceleyen çoklu regresyon analizi sonuçları detaylandırılmıştır. 
G. Özel - A. İnak 13/3 (2021) 2188-2202

Tablo 7: İş Yaşamında Yalnızlı̆̆ın Öğrenme Ataleti Üzerine Etkisini İnceleyen Çoklu Regresyon Analizi

\begin{tabular}{llllll}
\hline BAĞIMSIZ DEĞİŞKENLER & & & & \\
& BETA & T & SíG. (P) & Tolerance & VİF \\
\hline Sabit Değer &,- 102 &,- 508 &, 612 & & \\
\hline Duygusal Yoksunluk &, 683 & 19,962 &, $000^{* *}$ &, 966 & 1,035 \\
\hline Sosyal Arkadaşlık &, 088 & 2,573 &, $010^{*}$ &, 966 & 1,035 \\
\hline $\mathbf{F}$ & 219,462 & & & & \\
\hline $\mathbf{R}$ &, 705 & & & \\
\hline $\mathbf{R}^{2}$ &, 497 & & & \\
\hline Adjusted $\mathbf{R}^{2}$ &, 495 & & \\
\hline Durbin-Watson & 1,674 & & \\
\hline${ }^{*}$ Değer 0,05 düzeyinde anlamlıdır ** Değer 0,01 düzeyinde anlamlıdır \\
\hline
\end{tabular}

Öğrenme Ataleti= $\mathrm{f}$ (Duygusal Yoksunluk, Sosyal Arkadaşlık)

Model öğrenme ataleti düzeyi değişiminin \% 49,5 (adjusted R2)'ini açıklamaktadır. Diğer bir ifadeyle, turizm sektörü çalışanlarının iş yaşamında yalnızlık düzeyleri öğrenme ataleti düzeylerindeki değişimin \% 49,5'ini açiklamaktadır. Tablo 7'ye göre, iş yaşamında yalnızlığın, sosyal arkadaşlık ve duygusal yoksunluk boyutlarının öğrenme ataletine olan etkisinin pozitif ve doğrusal yönlü olduğu sonucuna ulaşılmıştır. Elde edilen bulgulara göre duygusal yoksunluk puanının bir birim artması durumunda öğrenme ataleti puanının da 0,683 (Beta1) kadar artacağını, sosyal arkadaşlık puanının bir birim artması durumunda ise öğrenme ataleti puanının 0,088 (Beta1) kadar artacağını söylemek mümkündür. Bu bilgiler 1şığında $\mathrm{H}_{1}$ hipotezini, $\mathrm{H}_{1 a}$ ve $\mathrm{H}_{1 \mathrm{~b}}$ alt hipotezlerini test etmek amaciyla belirlenen regresyon modeli $\mathrm{H}_{1}$ hipotezini destekler nitelikte olduğu görülmektedir. Bunun dışında, $\mathrm{H}_{1 a}$ ve $\mathrm{H}_{1 \mathrm{~b}}$ alt hipotezleri de kabul edilmiştir.

İş yaşamında yalnızlı̆̆ın deneyim ataleti üzerinde etkisi olup olmadığını belirlemek amacıyla iş yaşamında yalnızlık ölçeğinin her bir boyutunun deneyim ataleti üzerinde etkisini belirlemeye yönelik çoklu regresyon analizi uygulanmıştır. Tablo 7 'de iş yaşamında yalnızlığın deneyim ataleti düzeyleri üzerine etkisini inceleyen çoklu regresyon analizi sonuçları detaylandırılmıştır.

Tablo 8: İş Yaşamında Yalnızlığın Deneyim Ataleti Üzerine Etkisini İnceleyen Çoklu Regresyon Analizi

\begin{tabular}{llllll}
\hline BAĞIMSIZ DEĞIŞKENLER & BETA & $\mathbf{T}$ & SíG. (P) & Tolerance & VíF \\
\hline Sabit Değer &, 754 & 5,016 &, $000^{* *}$ & & \\
\hline Duygusal Yoksunluk &, 192 & 5,436 &, $000^{* *}$ &, 966 & 1,035 \\
\hline Sosyal Arkadaşlık &, 620 & 17,536 &, $000^{* *}$ &, 966 & 1,035 \\
\hline $\mathbf{F}$ & 192,628 & & & & \\
\hline $\mathbf{R}$ &, 682 & & \\
\hline $\mathbf{R}^{2}$ &, 465 & & \\
\hline Adjusted R &, 462 & & \\
\hline Durbin-Watson & 1,595 & & \\
\hline${ }^{*}$ Değer 0,05 düzeyinde anlamlıdır ** Değer 0,01 düzeyinde anlamlıdır &
\end{tabular}

Model deneyim ataleti düzeyi değişiminin \% 46,2 (adjusted $\mathrm{R}^{2}$ )'sini açıklamaktadır. Diğer bir ifadeyle, turizm sektörü çalışanlarının iş yaşamında yalnızlık düzeyleri deneyim ataleti düzeylerindeki değişimin \% 46,2'sini açıklamaktadır. Tablo 8'e göre, iş yaşamında yalnızlığın, sosyal arkadaşlık ve duygusal yoksunluk boyutlarının deneyim ataletine olan etkisinin pozitif ve doğrusal yönlü olduğu sonucuna ulaşılmıştır. Elde edilen bulgulara göre duygusal yoksunluk puanının bir birim artması durumunda öğrenme ataleti puanının 0,192 (Beta1) kadar artacağını, sosyal arkadaşlık puanının bir birim artması durumunda ise öğrenme ataleti puanının 0,620 (Beta1) kadar artacağını söylemek mümkündür. Bu bilgiler ışığında $\mathrm{H}_{2}$ hipotezini, $\mathrm{H}_{2 a}$ ve $\mathrm{H}_{2 b}$ alt hipotezlerini test etmek amaciyla belirlenen regresyon modeli $\mathrm{H}_{2}$ hipotezini destekler nitelikte olduğu görülmektedir. Bunun dışında $\mathrm{H}_{2 a}$ ve $\mathrm{H}_{2 b}$ alt hipotezleri de kabul edilmiştir. 


\section{SONUÇ VE ÖNERILER}

Bireysel atalet olan bir örgütte atalet yaygınlaşır, yalnızlık hissi yaşayan bireyler ise kendini örgüte ait hissetmeme ve dışlanma hissine kapılabilir. Bu nedenle misafir memnuniyeti, imaj, tanıtım, kaliteli hizmet sunumu, çalışanların motivasyonlarının sağlanarak verimliliklerinin arttırılması, örgüte bağlılıklarının artarak sorumluluklarını yerine getirmeleri için yalnızlık ve atalet çözülmesi gereken bir sorunlar olarak görülebilir. Bu kapsamda turizm sektöründe mevcut durumu belirlemeye yönelik olarak yapılan çalışmada katılımcıların iş yaşamında yalnızlık düzeylerinin 3,37 atalet düzeylerinin ise 3,21 ile oldukça yüksek değerler aldığı saptanmıştır.

Değişkenler arası ilişkileri belirlemeye yönelik yapılan korelasyon analizine göre, iş yaşamında yalnızlık düzeyini oluşturan duygusal yoksunluk boyutu ile ataletin alt boyutları olan öğrenme ataleti ve deneyim ataleti arasında anlamlı ve pozitif yönlü ilişki tespit edilmiştir. Aynı şekilde iş yaşamında yalnızlık düzeyinin alt boyutu olan sosyal arkadaşlık ile ataletin boyutlarından olan öğrenme ataleti ve deneyim ataleti boyutları arasında anlamlı ve pozitif yönlü ilişki tespit edilmiştir. Aynı zamanda iş yaşamında yalnızlık ile atalet arasında anlamlı ve pozitif yönlü ilişki tespit ediliştir. Bu kapsamda kişilerin duygusal yoksunlukları ve sosyal arkadaşlıklarında meydana gelen artışın öğrenme ve deneyim ataletini de artıracağını söylemek mümkündür.

Değişkenler arası etkiyi belirlemeye yönelik yapılan çoklu regresyon analizine göre, iş yaşamında yalnızlı̆̆ın öğrenme ataleti üzerinde değişimin \%49,5'ini açıladığı, iş yaşamında yalnızlığın alt boyutlarını oluşturan duygusal yalnızlık ve sosyal arkadaşlık boyutlarının öğrenme ataleti üzerinde pozitif yönlü anlamlı etkisi olduğu saptanmıştır. Deneyim ataleti üzerinde etkisine bakıldığında ise iş yaşamına yalnızlığın deneyim ataleti düzeylerindeki değişimin \%46,2'sini açıkladığı, duygusal yoksunluk ve sosyal arkadaşlığın deneyim ataleti üzerinde de pozitif yönlü anlamlı etkiye neden olduğu tespit edilmiştir. Elde edilen sonuçlara göre araştırmada $\mathrm{H}_{1}, \mathrm{H}_{1 a}, \mathrm{H}_{1 b}, \mathrm{H}_{2}, \mathrm{H}_{2 \mathrm{a}}, \mathrm{H}_{2 b}$ hipotezleri kabul edilmektedir.

Araştırmada elde edilen analiz sonuçlarına göre konaklama tesislerinde çalışan işgörenlerin iş yaşamında yalnızlık ve atalet düzeylerinin oldukça yüksek olduğu, iş yaşamında yalnızlığın çalışanlarda atalet halinin oluşmasında etkili olabileceğini söylemek mümkündür. Bu kapsamda turizm sektöründe insan faktörünün önemi göz önüne alındığında yalnızlık ve ataletin giderilmesi gereken sorunlar olarak görülmesi gerekmektedir. İşgörenleri yalnızlığa itecek faktörlerin ortadan kaldırılmasına kapsamında çalışanların motivasyonlarını artırmaya yönelik; sosyal etkinliklerin yapılması, etkin bir iletişim ağının oluşturulması, kararlara katılımlarının sağlanması, kişilerarası sosyal etkileşimi sağlayacak grupların oluşturulması, kariyer fırsatlarının oluşturulması, çeşitli eğitimlerin verilmesi, bireylerarası yaşanan sorunlara etkin çözümler getirilebilmesiyle birlikte hedeflerini belirleyerek ulaşmaları kapsamında desteklenmeleri, kendilerine güvenlerinin sağlanarak bir gruba ait hissetmeleri kapsamında örgütte paylaşımcı bir ruhun oluşturularak takım çalışmasına önem verilmesi, iş arkadaşları ve yönetimin desteğinin sağlandığı birlik duygusunu yaşayabilecekleri bir örgüt ikliminin oluşturulması gerekmektedir. Bu sayede kendini ifade edebilen, kendini örgüte ait hisseden işgörenler ile memnun çalışanların memnun misafirler oluşturacağ hareketle işgörenlerin yalnızlığa itecek faktörlerin ortadan kaldırılarak atalet düzeylerini etkilemesini önlemeye yönelik sistemin işletme içerisinde yerleştirilmesi gerekmektedir.

Yapılan literatür taramaları sonucunda yalnız bireylerin düşük benlik saygısına ve zayıf psikolojik sağlamlığa sahip olduğu (Güloğlu ve Karaırmak, 2012: 81), iş yaşamında yalnızlığın; örgütsel sinizm (Ay, 2015:1124) ve işten ayrılma niyeti üzerinde etkisi olduğu (Demirbaş ve Haşit, 2016: 152; Erdirençelebi, Ertürk ve Çini, 2020: 46), işyeri arkadaşlı̆̆ının işgören performansını etkilediği (Uluçay ve Zengin, 2020: 46), yalnızlı̆̆ın temel nedeninin örgütteki ilişki ve iletişim eksikliği olduğu ve örgüt içi iletişimin örgütsel sinizm üzerinde anlamlı negatif yönde etkisi olduğu (Tınaztepe, 2012:60) saptanmış olup atalet ile iş yaşamında yalnızlık kavramlarının birlikte ele alındığı çalışmaya rastlanmamıştır. Bu kapsamda yapılan çalışmanın sektöre, sektör temsilcilerine ve ilgili literatüre katkı sağlayacağı düşünülmektedir. İleride yapılacak çalışmalarda kavramların örgütsel güven, örgütsel vatandaşlık, örgütsel sessizlik, örgütsel adalet, işgören performansı, motivasyon gibi farklı değişkenler üzerinde etkisinin ölçülmesi önerilmektedir. Ayrıca araştırmanın uygulanma aşamasında mevcut covid-19 salgını çalışanlara ulaşma anlamında sınırlılık olarak görüldügünden çalışmanın sürecin normale dönmesiyle birlikte daha geniş bir örneklem grubuyla tekrarlanmasında fayda bulunacağı düşünülmektedir. 
G. Özel - A. İnak 13/3 (2021) 2188-2202

\section{KAYNAKLAR}

Akbaba, M. (2020). İnsan kaynakları yönetimi uygulamaları ile iş yaşamında yalnızlık arasındaki ilişki: otel işletmeleri üzerine bir araştırma, Turkish Studies-Social, 15(4), 1701-1716.

Aksoy, A. ve Türk, M. (2015). Bilgi ataleti ve örgütsel öğrenmenin girişimci davranış üzerine olan etkisi: Osmaniye ili organize sanayi bölgesine yönelik bir araştırma, Bitlis Eren Üniversitesi Sosyal Bilimler Enstitüsü Dergisi, 4(2), 1-28.

Altunışık, R., Coşkun, R., Bayraktaroğlu, S. ve Yıldırım, E. (2012). Sosyal Bilimlerde Araştırma Yöntemleri SPSS Uygulamalı, 7. Baskı, Sakarya, Sakarya Kitabevi.

Andersson, L. (1993). Loneliness and its relationship with misery. Psychological reports, 73(2), 584-586.

Ay, F.A. (2015). İstismarcı yönetim, işyeri yalnızlığı ve örgütsel sinizm arasındaki ilişkiler: sağlık çalışanlarına yönelik bir çalışma, Uluslararası Sosyal Araştırmalar Dergisi, 8(41), 1116-1126.

Bakan, İ., Sezer, B. ve Kara, C. (2017). Bilgi yönetiminin örgütsel çeviklik ve örgütsel atalet; üzerindeki etkisi: bir alan araştırması, Kahramanmaraş Sütçü İmam Üniversitesi İIBF Dergisi, 7(1), 117-138.

Besse, R. D. (2016). Loneliness among college students: examining potential coping strategies and the influence of targeted messages on the likelihood of befriending, Kansas State University, Doctoral dissertation,

Boz, H. ve Alan, H. (2021). İş yaşamında yalnızlık, çalışmaya tutkunluk, yaşam tatmini ve iş tatmini arasındaki ilişkilerin incelenmesi: turizm sektörü incelemesi. Manisa Celal Bayar Üniversitesi Sosyal Bilimler Dergisi, 19(2), 253-272.

Bozkurt, Ö. (2019). Örgütsel Yalnızlık, Kaygın, E. ve Kosa, G. (Ed.), Olumsuz Boyutlarıyla Örgütsel Davranı̧, Eğitim Yayınevi, Konya, s.61-75.

Çankaya, İ.H., ve Demirtaş, Z. (2010). Öğretmen adaylarının görüşlerine göre üniversite iklimi ve atalet arasındaki ilişki, Pamukkale Üniversitesi Eğitim Fakültesi Dergisi, 28(28), 1-9.

Çavuş, M.F. ve Pekkan N.Ü. (2017). Bilgi ataletinin karar verme tarzına etkisi, Uluslararası İktisadi ve İdari Incelemeler Dergisi, 10(19), 563-576.

Çetin, A. ve Alacalar, A. (2016). İş yaşamında yalnızlığı yordamada kişilik özellikleri ile algılanan sosyal ve örgütsel desteğin rolü, Uluslararası Yönetim İktisat ve İşletme Dergisi, 12(27), 193-216.

Demirbaş, B. ve Haşit, G. (2016). İş yerinde yalnızlık ve işten ayrılma niyetine etkisi: akademisyenler üzerine bir uygulama, Anadolu Üniversitesi Sosyal Bilimler Dergisi, 16(1), 137-158.

Doğan, T., Çetin, B. ve Sungur, M.Z. (2009). İş yaşamında yalnızlık ölçeği Türkçe formunun geçerlilik ve güvenilirlik çalışması, Anadolu Psikiyatri Dergisi, 10(4), 271-277.

Dönmez, F. G. ve Topaloğlu, C. (2020). Otel çalışanlarında algılanan örgütsel destek, iş yeri yalnızlığ ve iş tatmini ilişkisi. İş ve İnsan Dergisi, 7(2), 311-324.

Erdirençelebi, M., Ertürk, E. ve Çini, M.A. (2020). Örgütsel yalnızlık ile işten ayrılma niyeti ilişkisinde örgütsel sessizliğin aracilık etkisi, Sosyal Ekonomik Araştırmalar Dergisi, 20(39), 32-52.

George, D., ve Mallery, P. (2010). SPSS For Windows Step By Step. A Simple Study Guide and Reference (10. Baskı). GEN, Boston, MA: Pearson Education, Inc.

Gierveld, J.J, Tilburg, T. ve Dykstra, P. A. (2006). Loneliness and social isolation in D. Perlman ve A. Vangelisti (Ed), The Cambridge handbook of personal relationships (ss. 485-500). Cambridge University Press.

Güloğlu, B. ve Karaırmak, Ö. (2012). Üniversite öğrencilerinde yalnızlığın yordayıcısı olarak benlik saygısı ve psikolojik sağlamlık, Ege Eğitim Dergisi, 11(2), 73-88.

https://sozluk.gov.tr/ (Erişim tarihi: 15 Ocak 2021). 
G. Özel - A. İnak 13/3 (2021) 2188-2202

Jung, H. S., Song, M. K., ve Yoon, H. H. (2021). The Effects of Workplace Loneliness on Work Engagement and Organizational Commitment: Moderating Roles of Leader-Member Exchange and Coworker Exchange. Sustainability, 13(2), 948.

Karayel, G. (2014). Ortaöğretim Öğretmenlerinin Örgütsel Atalet Düzeyleri: Bayrampaşa İlçesi Örneği, Okan Üniversitesi Sosyal Bilimler Enstitüsü, Yüksek Lisans Tezi.

Keser, A. ve Karaduman, M. (2014). İş yaşamında yalnızlık algısının örgütsel vatandaşlık davranışı ile ilişkisi ve öğretmenler üzerinde bir araştırma, HAK-İŞ Uluslararası Emek ve Toplum Dergisi, 3(7), 178-197.

Küçükergin, K.G. (2012). Müşteri Sadakatinin Oluşum Sürecine Müşteri Tatmini ve Atalet İlişkisi: Yiyecekİçecek İşletmelerine Yönelik Bir Uygulama, Gazi Üniversitesi Sosyal Bilimler Enstitüsü, Yüksel Lisans Tezi.

Liao, S. H. (2002). Problem solving and knowledge inertia. Expert systems with applications, 22(1), 21-31.

Liao, S., Fei, W. ve Liu, C. (2008). Relationships between knowledge inertia, organizational learning and organization innovation, Technovation, 28(4), 183-195.

Mercan, N., Demirci, K., Özler, D.E. ve Oyur, E. (2015). İş yaşamında yalnızlık, duygusal zekâ ve psikolojik sermaye arasındaki ilişkiler üzerine bir araştırma, Manas Sosyal Araştırmalar Dergisi, 4(5), 197-211.

Özkoç, A.G. (2014). Turizm İşletmelerinde Örgütsel Güven, Tükeltürk, Ş.A., Perçin N.Ş. ve Güzel, B. (Ed.), Turizm İşletmelerinde Çalışan İlişkileri Yönetimi, Detay Yayıncılık, Ankara, s. 39-58.

Roodt, G., Kinnear, C., ve Erwee, R. (2003). Organisational inertia: contrasting results in Australiaand South Africa, SA Journal of Industrial Psychology, 29(2), 1-5.

Sekman, M. (2009). Kişisel Ataleti Yenmek, İstanbul, Alfa Basım Yayım.

Şahin, B., Kutluk, A., Mayuk, A. ve Köstekli, E. (2011). Turizmde rekabet avantajı için değişim mühendisliğinin küçük ve orta büyüklükteki otel işletmelerinde uygulanması. Öncü, M.A. (Ed.),. 12. Ulusal Turizm Kongresi Bildiri Kitabı, Düzce, Sidas Medya, 570-581.

Tınaztepe, C. (2012). Örgüt içi etkin iletişimin örgütsel sinizme etkisi, Organizasyon ve Yönetim Bilimleri Dergisi, 4(1), 53-63.

Topaloğlu, C. (2010). Örgüt içi çatışmaların yönetim süreci: otel işletmeleri açısından kuramsal bir değerlendirme, Sosyal Ekonomik Araştırmalar Dergisi, 10(20), 97-114.

Uluçay, E. ve Zengin, Y. (2020). İşyeri arkadaşlığı ve işgören performansı arasındaki ilişki: bir araştırma, Turkish Business Journal, 1(1), 29-50.

Wright S.L, Burt C.D.B. ve Strongman, K.T. (2006). Loneliness in the workplace: construct definition and scale development, New Zealand Journal of Psychology, 35(2), 59-68.

Wright, S.L. (2005). Loneliness in the Workplace. Doctoralthesis, New Zealand, University of Canterbury.

Yakut Aymankuy, Ş. (2001). Turizm sektöründe kriz yönetimi, Balıkesir Üniversitesi Sosyal Bilimler Dergisi, 6(), 105-118.

Yakut, S. ve Certel, H. (2016). Öğretmenlerde yalnızlık düzeyinin çeşitli değişkenler açısından incelenmesi, Birey ve Toplum Sosyal Bilimler Dergisi, 6 (1), 69-94.

Yılmaz, E. ve Aslan, H. (2013). Öğretmenlerin işyerindeki yalnızlıkları ve yaşam doyumları arasındaki ilişkinin incelenmesi, Pegem Eğitim ve Öğretim Dergisi, 3(3), 59-69.

Yurcu, G. ve Kocakula, Ö. (2015). Konaklama işletmelerinde çalışan yalnızlığının öznel iyi oluş üzerine etkisi, Adnan Menderes Üniversitesi Sosyal Bilimler Enstitüsü Dergisi, 2(1), 30-41. 